\title{
The Role of Trees and Pastures in Organic Agriculture
}

\author{
Joseph R. Heckman ${ }^{1}$ \\ ${ }^{1}$ Plant Biology Department, Rutgers University, New Brunswick, NJ 08901, United State \\ Correspondence: Joseph R. Heckman, Plant Biology Department, Rutgers University, New Brunswick, NJ 08901, \\ United State. E-mail: heckman@aesop.rutgers.edu
}

Received: January 31, 2015 Accepted: April 17, 2015 Online Published: June 20, 2015

doi:10.5539/sar.v4n3p51

URL: http://dx.doi.org/10.5539/sar.v4n3p51

\begin{abstract}
Environmental concerns associated with annual row crop grain production - including soil erosion, soil carbon loss, intensive use of chemicals and petroleum, limited arable land, among others - could be addressed by converting conventional livestock production to an organic pasture based system. The inclusion of tree crops would further enhance the opportunity for feeding pasture- raised livestock by providing shelter and alternative feed sources. Biodiversity is an essential aspect of an organic farm plan. The idea of including tree crops and other perennials into the vision of an organic farm as a "living system" is very much compatible with the goals and philosophy of organic farming. Before modern no-till farming systems were developed, tree crops and pasture systems were found to provide similar benefits for controlling soil erosion and conserving soil carbon. For example, J. Russell Smith's Tree Crops: A Permanent Agriculture (Smith, 1950) and pioneered tree crop agriculture as the alternative to annual row crops for protecting soils from erosion while producing livestock feed such as acorns, nuts, and fodder. A survey of Mid-Atlantic USA soils under pasture found $60 \%$ higher soil organic matter content than cultivated fields. Because United States Department of Agriculture's National Organic Program (USDA-NOP) standards require dairy cattle consume pasture forage and limited grain (7 C.F.R pt. 206), organic milk contains higher concentrations of omega-3 and fewer omega- 6 fatty acids than conventional milk. Organic standards also state "the producer must not use lumber treated with arsenate or other prohibited materials for new [fence posts] installations or replacement purposes in contact with soil or livestock." Black locust (Robinia pseudoacacia) is a fast growing renewable alternative to treated lumber with many attributes compatible with organic farming. This versatile tree fixes nitrogen $(\mathrm{N})$, provides flowers for honey bees and other pollinators, and produces a highly durable dense wood ideal for fence posts useable for up to 50 year.
\end{abstract}

Keywords: soil quality, biodiversity, livestock, milk, fat soluble vitamins, silvopasture

\section{Introduction}

Organic agriculture operates as an ecologically-oriented management system integrating trees and pasture into productive farming operations, especially those including livestock. This paper reviews the theoretical foundation and current regulatory requirements underlying organic agriculture's ecological orientation and then examines specific aspects of the ecological functions of trees and pasture on organic farms with livestock.

The very earliest characterizations of organic agriculture emphasized its ecological foundations by identifying it as a closed loop system in which farmers balance productivity, efficiency and stability by managing natural resources through biological processes. For example, widely acknowledged (Heckman, 2013; Paull, 2011; Tanner \& Simonson, 1993) as the seminal work on organic agriculture, Farmers of Forty Centuries, Permanent Agriculture in China Korea, and Japan (King, 1911) described the scrupulous recycling of natural resources through biologically-driven practices. These included the use of composting, manures, cover cropping with legumes and crop rotation to explain the continuous cultivation of the same crop land for more than four millennia by Asian peasant farmers. King, a former Chief of Soil Management at the United States Department of Agriculture (USDA) and a number of his peers had grown alarmed by the rapid deterioration of soil quality on domestic farmland managed for a fraction of that period. King identified the parallels between traditional Asian farming practices and naturally occurring ecological systems, especially the continuous recycling of inputs and the regeneration of soil fertility through internal processes, as the foundational tenets of what others would later define as organic agriculture (Northborne, 1940; Conford, 2001; Heckman, 2006). 
Perhaps most notable among King's theoretical descendants was Sir Albert Howard who often co-authored with his wife, Lady Gabrielle Howard, journal articles and books based on their many years of research experience with the traditional farming systems of India. In their view, an ideal organic farm functioned as a living entity bound together through the "great linkage between the soil, the plant and the livestock" (Howard, 1947). This characterization from The Soil and Health emphasizes the centrality of an integrated, biologically-driven and self-sustaining operation underpinning organic agriculture. According to Howard, "Mother earth never attempts to farm without livestock; she always raises mixed crops; great pains are taken to preserve the soil and to prevent erosion; the mixed vegetable and animal wastes are converted into humus; there is no waste; the processes of growth and the processes of decay balance one another; ample provision is made to maintain large reserves of fertility; the greatest care is taken to store the rainfall; both plants and animals are left to protect themselves against disease." (Howard, 1947)

Like King, Howard and those who came to embrace his holistic approach to agricultural management were deeply skeptical of the rapid transformation of agriculture during the twentieth century. These changes included the introduction of synthetic fertilizers and pesticides, the mechanization of agricultural labor and the specialization of farms into monocultures segregating crop and livestock production. Adoption of these more industrialized production practices contributed to measurable decreases in soil biological activity and wild biodiversity sharing the agricultural landscape. Howard noted that by increasing dependence on purchased non-renewable inputs, especially for fertility and energy, these agricultural innovations undermined the organic principle that farms should be self-sustaining. He also observed that diminishing the ecological integrity of a farming system would inevitably diminish the integrity of the food it produced.

The term "organic" as a system of farming was first put forth by Lord Walter Northborne (1940) in his book Look to the Land. Before this terminology was adopted Howard described his model of farming as "nature farming" where natural ecosystems served as models. Consistent with observations from natural ecosystems, and drawing from the work of King, Howard stressed the principle of the "law of return." Farming by this principle means that all types of natural and organic waste products are to be recycled to soil (Heckman et al., 2009). Composting was used to process and prepare these materials for return to the land.

The idea of an organic farm functioning as a living system was further characterized by Walter Northborne in terms of "wholeness" as in an organic farm "must have a biological completeness" and have a "living entity" where every "branch of the work is interlocked with all others" (Northborne, 1940). Other organic pioneers that followed further elaborated these agro-ecological principles underlying organic farming (Balfour, 1976; Coleman, 2011). A living organic farm would ideally include trees, pastures, and livestock as valuable components of the system (Wild Farm Alliance, 2008). Crop rotation, composting, and closure of nutrient cycles are additive practices and monocultures segregating crop and livestock production are limiting practices.

Historically and philosophically organic agriculture has embraced biodiversity as a way of creating an ecological system of farming. Furthermore, USDA- NOP standards mandates conservation of biodiversity National Organic Program 7 C.F.R. pt 205 (2015); USDA, Draft Guidance for National Resources and Biodiversity Conservation for Certified Organic Operations, (2015), with trees, pastures, and livestock regarded as valuable organisms to work into an organic farm plan. As a result and in contrast to modern conventional agriculture, where a few annual row crops dominate the production system on an industrial scale, organic farming systems are more likely to utilize many woody and herbaceous perennials and forbs of pastures for food and fiber production.

These ecological practices that include increased biodiversity, crop rotation, and avoidance of monoculture are factors that enable a farm to function effectively as an "organic living system."

\section{Agronomic Role of Pasture in Organic Farming}

In modern conventional farming the separation of crop production from livestock is the norm and the use of synthetically manufactured $\mathrm{N}$ substitutes for biologically based N. Well-designed organic farming systems can acquire sufficient $\mathrm{N}$ for crop production by careful management of the $\mathrm{N}$ cycle (Heckman et al., 2009; Adam et al., 2012). This requires practicing the "law of return" (Howard, 1947) for natural waste materials, composting, crop rotation with legumes, and cover crops among other organic practices. The Haber-Bosch (Smil, 2004) process for industrial $\mathrm{N}$ manufacture allows conventional farmers to forego these and is widely regarded as a necessary invention for feeding humanity (Erisman et al., 2008). This assumption is seldom questioned (Heckman, 2013).

The use of synthetic $\mathrm{N}$ fertilizers enabled separation of crop production from livestock operations, decreased the emphasis on feeding livestock on pastures and forages, encouraged the movement towards concentrated feeding operations, and increased problems associated with poor utilization of manures. Organic livestock farming 
systems in general and especially dairy in particular, tend to run counter to these trends with better integration of crop and livestock production. In fact, NOP standards require pastures for dairy operations (National Organic Program, 7CFR, Part 205.240 (2015)) and prohibit monocultures (National Organic Program, 7 CFR, Part 205.203 (2015)).

Well before organic was founded as a system of farming, a popular soil fertility textbook (Vivian 1908) recognized that pasture-based dairy farming was one of the most economical and effective ways to maintain soil fertility. Organic farms with NOP compliant crop rotations integrated with pastures and perennial legumes, can normally supply adequate $\mathrm{N}$ for crops (Heckman et al., 2009; Kirschenmann, 2007; Clark, 2009). As a result an $\mathrm{N}$ deficiency in crops may be regarded as deficiency of the farming system.

A survey of fields in the Mid-Atlantic region of the USA measured 60\% more organic carbon in the top $15 \mathrm{~cm}$ of pastureland compared to soils under annual row crop (Heckman et al., 2010). This accumulated soil organic matter associated with pasture serves as a reservoir for stored $\mathrm{N}$ (Heckman et al., 2009). Pasture forage generally includes a mix of grasses and legumes. The legume produces on-farm $\mathrm{N}$ and the dense root systems of grass plants prevent the leaching of $\mathrm{N}$ from the soil (Heckman et al., 2009). Soil building can also be accomplished by growing cover crops (Sustainable Agriculture Research and Education Program, 2007). While cover crops do provide many useful ecosystem services, pastures and forage crops consumed by livestock also serve to both feed the life in the soil and at the same time produce nutrient rich food for people. When or if pasture sod is eventually broken or tilled for the purpose of rotating to row crop grains, the accumulated soil fertility is released. In such rotations there is generally little or no need for purchase of off-farm nitrogen fertilizers. A special feature of the $\mathrm{N}$ cycle in organic farming is that it is largely solar powered (Heckman et al., 2009) in contrast with the Haber-Bosh process where industrial $\mathrm{N}$ fixation is produced with natural gas (Smil, 2001).

Soil improvement is a stated goal of the USDA-NOP standards (NOP 7CFR 205.203 (2015)) National Organic Program). Rotations using perennial forages and pastures are good ways to achieve this objective. Well-managed perennial pastures maintain soil cover and protect against erosion. Also pasture serves as a cover crop while at the same time enables a cash flow through sales of animal products. In contrast, cover crops grown strictly as vegetative cover, may in some regions, tie-up a fraction of the growing season without producing food or an income stream. Well managed perennial pastures maintain soil cover and protect against erosion. Although almost rarely stated as such, pasture-based farming is in fact a no-till farming system and has advantages over conventional no-till farming systems with annual crops because of the dependence on chemical herbicides and synthetic N. These advantages include conservation of time and energy for planting, permanent living ground cover to prevent soil erosion and leaching of nutrients, and maintaining a pleasantly green pastoral scenery for the viewing public (Franzluebbers, 2009; Heckman, 2012).

\section{Role of Pasture in Organic Farming on Food}

Beyond encouraging good soil management the USDA-NOP standards say little about how organic farming methods may improve food quality or human health. The pioneers of the organic farming movement, however, were very much concerned with connections between soil health, food quality, and human health (Howard, 1972). Albert Howard for example wrote that "Soil fertility is the basis of the public health system of the future". The Farming Systems Trial (FST) at the Rodale Institute comparing different management schemes over three decades has demonstrated remarkable improvements in soil quality in association with organic management practices (Rodale, 2013). The further step of making the connection between farming system and human health, however, remains tenuous (Carr et al., 2012). Consumers frequently ask if there are any meaningful differences in organic versus conventional foods. For plant based foods there has been has an ongoing unsettled debate. What is clear is that organic plant based foods generally have less pesticide residue (Baker et al., 2002)

Fewer studies have examined animal based foods as a way of comparing organic versus conventional production. At least for dairy products the organic versus conventional nutritional differences are measurably evident based on laboratory analysis. A recent study (Benbrook et al., 2013) looked at the type of fats in organic vs. conventional milk across the USA. In almost every region there was a significant difference in the omega 6 / omega 3 ratios. The one exception was in Northern California where organic and conventional dairy cows are both pasture-based. In all other regions the ratio was more favorable for organic milk because in those cases pasture was a more significant feed source for the organic cows. The study also found that conjugated linoleic acid (CLA), in pasture-raised organic milk increases in the spring and summer months in association with the return of cows to pasture. Concentrations of CLA in organic milk are maximized during grazing season while in the conventional milk it remains flat regardless of season. The relatively new USAD-NOP pasture standard requiring grazing for $30 \%$ or more of dry matter intake may be a key factor (NOP 7 CFR Part 205.240). The 
authors of this study (Benbrook et al., 2013) on how organic production enhances milk quality conclude that "increasing reliance on pasture and forage-based feeds on dairy farms has considerable potential to improve the FA [fatty acid] profile of milk and dairy products" and "it is far more common - and indeed mandatory on certified organic farms in the U.S. - for pasture and forage-based feeds" and "improvements in the nutritional quality of milk ... should improve long-term health status and outcomes, especially for pregnant women, infants, children, and those with elevated CVD [cardiovascular disease] risk." Other studies have also reported differences in composition of animal products as a result of pasture feeding. A review on Grass and Human Nutrition by Karsten and Baer (2009) found that in meat, milk, and eggs there are higher levels of CLA, and vitamins $\mathrm{A}, \mathrm{E}$, and $\mathrm{B} 12$.

\section{Needed Research on Pasture-Raised Animals and Food}

Pasture-raised animal foods are generally believed to be good sources of the fat soluble vitamins A, D, E, and K2 (Rheaume-Bleue, 2012). Only a few studies, however, have measured vitamins D and K2 in meat, milk, and eggs in association with type of production system. A study comparing pasture feeding to confinement layers found that pasture enhanced vitamin A and E content in eggs (Karsten et al., 2010). However, they did not measure vitamins D or K2.

The organic pioneers were especially interested in how food systems influenced human health. Eve Balfour (1976), for example, as shown in her book The Living Soil, attempts to interpret and summarize the work of Dr. Weston A. Price and other nutrition pioneers. Albert Howard and Jerome Rodale (1948) also discussed the findings of Dr. Price. Weston (1950) was a dentist who studied nutrition and traditional diets in relation health. The presumption was made that the peoples studied were eating "organic" before there was any type of certification. Price's work had a particular focus on fat soluble vitamins. This aspect of his work was mostly unappreciated or misunderstood by many of the organic pioneers. In all healthy groups Price studied, had a rich source of something he termed the "X-factor" in their diets. Current research indicates that this X-factor was very likely vitamin K2 (Rheaume-Bleue 2012, Flore et al., 2013). Price was able to isolate and concentrate this $\mathrm{X}$-factor from butter produced by cows eating rapidly growing green grass. This unidentified substance served as a catalyst for mineral adsorption and helped people develop excellent teeth and bones. This so called X-factor has properties that match up very well with what has since become known as vitamin K2 (Masterjohn, 2007a). In a review, Masterjohn (2007b) argues the case that it is in fact vitamin K2.

Vitamin K2 has historically been underrated and misunderstood because of confusion with vitamin K1. Vitamin $\mathrm{K} 1$ aids in blood clotting. Vitamin K2 can also do this but much more. Because vitamin K1 is recycled in the body deficiency is rare. Vitamin K2 is a catalyst for mineral absorption especially for calcium (Ca). Vitamin K2 protects heart health and builds strong bones and teeth. Taking calcium or vitamin D supplements alone without sufficient vitamin K2 intake may lead to nutritional imbalances. Vitamin K2 works in association with vitamins A and D - the so called "fat soluble vitamins". Some preliminary evidence suggests that animals grazing good pasture concentrate vitamin K2 in milk, meat, and eggs (Rheaume-Bleue, 2012).

More research is needed on vitamin K2 sources and influence of organic farming systems on its levels in food. Vitamin K2 levels in organic milk may follow a trend similar to CLA levels. When the organic cows are pastured in the spring and summer months, vitamin $\mathrm{K} 2$ levels in milk butter fat may similarly increase. The molecular precursor to vitamin $\mathrm{K} 2$ is phylloquinone which would be concentrated in the green leaves of pasture plants. Grazing animals convert this phylloquinone to vitamin K2 (Rheaume-Bleue, 2012). In order for people to receive the benefits from the presence of fat soluble vitamins in pasture-raised foods they must eat sufficient amounts of fat (Masterjohn, 2013). Unfortunately modern dietary guidelines have unwisely warned against eating animal fats (Hoenselaar, 2012).

\section{Pasture Feeding}

Once a dairy farmer decides to put cows on pasture, taking the next step to go organic is relatively easy (Dr. Hubert Karreman, personal communication). However, pasture feeding is not a dairy farming system that maximizes per cow production, but it is in line with traditional organic philosophy of "Refusing to Push the Cows" (Saucier 2014). For a variety of reasons, pasture feeding included, organic dairy operations generally have fewer animal health problems (Karreman, 2007). Good animal health and prevention are critical aspects of all animal husbandry. This is especially important because many of the usual veterinary drugs are prohibited for organic dairy production (Karreman, 2007; Karreman, 2011).

Beyond a system of production, pasture feeding influences consumer demand and marketing (Dmitri \& Oberholtzer, 2009). With increasing awareness about the effect of pasture feeding on food quality and animal welfare, increasing numbers of people are seeking out pasture-raised animal products (Black, 2015). Perhaps, to 
the extent that USDA-NOP encourages livestock feeding on pasture, consumers seek out the organic label.

Eggs produced by chickens on pasture have a noticeable difference in quality and color, ranging from dark yellow to orange color of egg yolks is typical (Karsten \& Baer 2009). When chickens are given a chance to graze the leaves of wheat or rye plants in the winter, the egg yolks take on an especially deep orange character (Heckman, 2011). Currently little data is available on the nutritional quality or the levels of fat soluble vitamins in such eggs.

Unlike organic dairy, there is no specific pasture requirement for egg production, although the NOP rules do require "year-round access for all animals to the outdoors... (NOP 7 CFR 205.239)." Pasture only provides about $10 \%$ of feed for egg laying hens. One of the main benefits is that organic egg producers keeping hens on pasture may earn a price premium over the average organic egg. At Whole Foods grocery stores, pasture raised organic eggs are currently priced $\$ 8.99$ compared to $\$ 4.69$ for regular organic eggs, corresponding to a $91 \%$ higher price (Black, 2015).

\section{Example of a Pasture Based Organic Farm}

"The Family Cow" near Chambersburg, Pennsylvania is an example of a highly diversified pasture based organic farm. This farm has found ways to scale up poultry production on pasture where egg layers or broilers are rotated over pasturelands after the grazing of dairy cows. The manures deposited by the poultry fertilize the grass. The chickens may also help with fly control. A dog lives with the flock of egg layers to protect the birds from predators. The eggs are collected from the specially designed egg mobile wagons via a conveyer belt.

Farm tours, available by appointment from The Family Cow website, helps make this organic farming operation transparent and educational for the public. This rather innovative organic farm produces raw milk, eggs, broilers, turkeys, beef, and pork, all from animals on pasture. The farm products are directly marketed from an on-farm store and via their website and delivered to 48 receiving points in Pennsylvania. People buying from such diversified organic farms are able to purchase most of their food needs without going into a commercial grocery store. This integrated system of pasture farming and marketing was inspired by Joel Salatin (Edwin Shank, personal communication). Pasture-based farming systems have become popular with increasing awareness of the value of pasture raised foods as a result of the educational programs of the Weston A. Price Foundation, publication of the bestselling book The Omnivore's Dilemma by Michael Pollan, and documentary films such as Farmaggedon, American Meat, and Food Inc.

\section{Role of Trees in Organic Farming}

Tree crops offer additional ways to feed livestock. Silvopasture is a farming system that integrates trees with pastures. The trees in this system provide valuable shade and shelter and can also produce livestock feed such as seeds, fruit, nuts, acorns, flowers, or foliage (Brunetti, 2014).

The idea of feeding livestock with tree crops instead of annual row crop grains was promoted by J. Russel Smith in his classic book on Tree Crops, A Permanent Agriculture (Smith, 1950). Smith, a geographer traveled widely and witnessed extensive soil erosion on sloping lands. He proposed tree crops as a viable alternative form of agriculture for land areas vulnerable to soil erosion. He argued that if the same attention in plant breeding and selection used for annual crops were to be applied to tree crops, agricultural productivity could be greatly expanded on marginal lands. Researchers at Rutgers University, inspired by the concepts in Smith's book, seek to advance tree crops through a global search for germplasm resources for selection, and plant breeding. This work was initiated by the late Dr. Reed Funk who had made great advances in grass breeding before deciding to turn his attention to breeding tree crops (Molnar et al., 2013)

The Rodale Institute, a center for organic farming research, also has an active research program called "Tree as a Crop" (The Rodale Institute, 2015), recognizing that many farms have some land that can be devoted to trees. Managed as silvopastures, this land may be used for pasturing many kinds of livestock. On very hot, cold, or windy days, livestock may be protected by tree shelter.

\section{Special Attributes of Trees}

As perennials, trees have a range of beneficial attributes. For example, after establishment, their deep extensive root systems become a long-term no-tillage system offering protection against soil erosion. Many tree species, such as the oaks, have the potential to produce livestock feed. Unlike row crop grains, tree crops do not require annual applications of starter fertilizers. Also, the pattern of nutrient uptake from soil by trees takes place over extended periods of time whereas with annual cropping systems the nutrient uptake period is short. Once an annual root system dies it offers no resistance to leaching of nutrients. Tree crops tend to be less "leaky" of nutrients over the fall and winter seasons. Furthermore a large pool of nutrients are conserved within living 
tissues such as bark, stems, and roots, and these nutrients are recycled internally from season to season (Youssefi et al., 1999).

Compared to annual crops, one of the main disadvantages of tree crops is that they require more time between generations for plant breeding improvement. Probably for this reason, plant breeding efforts have focused primarily on selections of annuals for yield. Perennial crops and especially trees in particular offer an under-utilized opportunity for plant breeders to select for yield and other agronomic traits (Molnar et al., 2013).

Mainstream agriculture is dominated with the annual cropping paradigm but this could change if new proposals for establishing research programs and centers for tree crops were ever taken seriously. Greater use of both woody and herbaceous perennials could contribute significantly to the productivity of organic farming simply by exploiting their extended window for photosynthetic activity. This property was eloquently described by Wes Jackson (2011) "Humans have forever looked for ways to increase the food supply of the world when all around us, year in year out, it should be apparent that the most rewarding way would be to increase the proportion of the year when the land is covered by a photosynthesizing leaf canopy". In this way trees and pasture plants are well suited towards this goal in both conventional and organic agriculture.

\section{Trees Grow Natural Lumber and Fence Posts for Organic Farming}

Aside from direct roles in productivity, certain types of trees are valued for providing fiber, building materials, and shelter. Natural untreated wood products are especially valued in organic agriculture. For example, the USDA-NOP standards provide "The producer must not use lumber treated with arsenate or other prohibited materials" (NOP 7 CFR 205.206 (2015).

Some newly established organic pasture based farms in New Jersey, are reporting a short supply of available locust wooden post for fencing (Profeda Farms, personal communication). Black locust wood is very decay resistant with an effective useful life as a fence post of 50 years or more.

Black locust is a particularly valuable tree species in organic agriculture because it can serve so many useful functions (Chedzoy, 2015). It is a very fast growing leguminous tree that carries out biological $\mathrm{N}$ fixation. Because it casts only a light shade it performs very well in silvopasture systems. The tree is very easy to establish. After only about ten years of growth on good sites, the stems can be harvested as fence posts. After harvest, the trees regenerate quickly from stump sprouts. Thus, once established, there is no need to replant this most renewable resource. The wood is highly durable and decay resistant. The flowers on black locust trees are a favorite for honey bees.

A 1930, publication by the USDA Forest Service provides excellent guidance on growing black locust (USDA Farmers Bulletin No. 1628). One pest problem with black locust is the locust borer. Fortunately, this pest is absent from Europe where black locust is grown in plantations for many uses.

\section{Conclusion}

Trees and pasture thoughtfully integrated into the farm ecosystem have much to contribute to the sustainability of organic agriculture. Including pasture in a crop rotation is one of the most effective ways to build soil organic matter content. Herbaceous and woody perennials, even on hilly lands, protect soils from erosion. The nutritional quality of animal foods is improved when produced by livestock on pasture. People choosing to eat organic pasture raised foods are indirectly contributing to and helping fund soil improvement. Future research on organic food quality as it relates to pasture feeding of livestock should look beyond fatty acid composition to levels of the fat soluble vitamins A, D, E and K2 in the food product. Organic farmers building pasture fences and animal shelters may benefit from growing silvopastures that include black locust. The very durable wood from this tree is an excellent alternative to commercial lumber treated with unapproved toxic materials. Altogether, trees and pastures are parts of the living fabric of organic farms that create a web of connections between soils, plants, animals, and people while building healthy and sustainable ecosystems.

\section{Acknowledgements}

This project was supported by Organisation for Economic Co-operation and Development (OECD) Co-operative Research Programme, USDA-NIFA Organic Agriculture Research and Extension Initiative, and Rutgers New Jersey Agriculture Experiment Station. Special appreciation is extended to Mark Keating for helpful suggestions.

\section{References}

Adam, S. D., Jason, D. H., Craig, A. C., Johanns A. M., \& Liebman M. (2012). Increasing Cropping System Diversity Balances Productivity, Profitability and Environmental Health. PLOS, 7(10). Retrieved from http://journals.plos.org/plosone/article?id=10.1371/journal.pone.0047149 
Balfour, E. B. (1976). The Living Soil and the Haughley Experiment. New York, NY, USA: Universe Books.

Baker, B. P., Benbrook, C. M., Groth, E., \& Lutz, B. K. (2002). Pesticide Residues in Conventional, Integrated Pest Management (IPM) - Grown and Organic Foods: Insights from Three U.S. Data Sets. Food Additives and Contaminants, 19, 427-446. http://dx.doi.org/10.1080/02652030110113799

Benbrook, C. M., Butler, G., Latif, M. A., Leifert, C., \& Davis, D. R. (2013). Organic production enhances milk nutritional quality by shifting fatty acid composition: A united States-Wide 18-month study. PLOS, 8(12) http://dx.doi.org/10.1371/journal.pone.0082429

Black, J. (2015). How One Company is Trying to Make 'Pasture-Raised' the New Egg Standard. The Washington Post.

Brunetti, J. (2014). The Farm as Ecosystem, Tapping Nature's Reservoir - Biology, Geology, Diversity. Austin, TX: Acres USA.

Chedzoy, B. (2015). Forest Connect. Retrieved from http://www2.dnr.cornell.edu/ext/forestconnect/

Carr, P. M., Delate, K., Zhao, X., Cambardella, C. A., Carr, P. L., \& Heckman, J. R. (2012). Organic Farming Impacts on Soil, Food, and Human Health. In E.C. Brevik, \& L.C. Burgess. (Eds.), Soils and Human Health (p. 18), New York, NY: Taylor and Francis. http://dx.doi.org/10.1201/b13683-16

Clark, A. E. (2009). Forages in Organic Crop - Livestock Systems. In C. Francis. (Ed.), Agronomy Monographs 54 Organic Farming: The Ecological System (pp. 85-112). Madison, WI: Alliance of Crop, Soil and Environmental Science Societies. Retrieved from https://dl.sciencesocieties.org/publications/books/tocs/agronomymonogra/organicfarmingt

Code of Federal Regulations. (2015). National Organic Program, 7CFR1.205, 2014. http://www.ecfr.gov/cgi-bin/text-idx?tpl=/ecfrbrowse/Title07/7cfr205_main_02.tpl

Coleman, E. (2011). Organic agriculture: Deeply rooted in science and ecology. Retrieved from $\mathrm{http}$ //grist.org/sustainable-farming/2011-04-20-eliot-coleman-essay-organic/

Conford, P. (2001). The Origins of the Organic Movement. Glasgow, UK: Floris Books.

Dmitri, C., \& Oberholtzer, L. (2009). Marketing U.S. Organic Foods: Recent Trends from Farm to Consumers. Washington, DC: USDA Economic Research Service. Retrieved from http://www.ers.usda.gov/publications/eib-economic-information-bulletin/eib58.aspx

Erisman, J. W., Sutton, M. A., Galloway, J., Klimont, Z., \& Winiwater, W. (2008). How a century of ammonia synthesis changed the world. Nat. Geosci., 1, 636-639. http://dx.doi.org/10.1038/ngeo325

Flore, R., Ponziani, F. R., Di Rienzo, T. A., Zocco, M. A., Flex, A., Gerardino, L., ... Gasbarrini, A. (2013). Something more to say about calcium homeostasis: the role of vitamin K2 in vascular calcification and osteoporosis. Eur Rev Med Pharmacol Sci., 17(18), 2433-2440.

Franzluebbers, A. J. (2009). Farming with Grass: Achieving Sustainable Mixed Agricultural Landscapes. Ankeny, Iowa: Soil and Water Conservation Society.

Heckman, J. R. (2006). A History of Organic Farming: Transitions from Sir Albert Howard's War in the Soil to USDA National Organic Program. Renewable Agriculture and Food Systems, 21, 143-150. http://dx.doi.org/10.1079/RAF2005126

Heckman, J. R. (2013). Soil Fertility Management a Century Ago in Farmers of Forty Centuries. Sustainability, 5, 2796-2801. http://dx.doi.org/10.3390/su5062796

Heckman, J. R. (2012). Human Contact with Plants and Soils for Health and Well-Being. In E. C. Brevik \& L. C. Burgess (Eds.), Soils and Human Health (p. 14), New York, NY: Taylor and Francis. http://dx.doi.org/10.1201/b13683-15

Heckman, J. R., Weil, R., \& Magdoff, F. (2009). Practical Steps to Soil Fertility for Organic Agriculture. In C. Francis (Ed.), Agronomy Monographs 54 Organic Farming: The Ecological System (pp. 139-172). Madison, WI: Alliance of Crop, Soil and Environmental Science Societies. http://dx.doi.org/10.2134/agronmonogr54.c7

Heckman, J. R., Bhashyam, N., \& Hair, K. (2010). Soil Organic Matter Levels under Pastures and Row-Crops. Paper presented at 2010 International Annual Meetings of the American Society of Agronomy, Crop Science Society of America and Soil Science Society of America, Long Beach, CA. Abstract retrieved from https://a-c-s.confex.com/crops/2010am/webprogram/Paper58639.html 
Heckman, J. R. (2011). A Pasture Walk on the Home Turf. Retrieved from http://hartkeisonline.com/2010/06/03/backyard-poultry-farming-explained-by-soil-scientist/\#more-6562

Hoenselaar, R. (2012). Saturated Fat and Cardiovascular Disease: The Discrepancy between the Scientific Literature and Dietary Advice. Nutrition, 28, 118-123. http://dx.doi.org/10.1016/j.nut.2012.04.009

Howard, A. (1972). The Soil and Health., New York, NY: Schocken Books. (1972 edition of Soil and Health which was originally published in 1945).

Jackson, W. (2011). Consulting the Genius of the Place. Berkeley, CA: Counterpoint.

Karreman, H. (2007). Treating Dairy Cows Naturally: Thoughts and Strategies. Austin, TX: Acres USA.

Karreman, H. (2011). The Barn Guide to Treating Dairy Cows Naturally: Practical Organic Cow Care for Farmers. Austin, TX: Acres USA.

Karsten, H. D., \& Baer, D. (2009). Grass and Human Nutrition. In W. F. Wedin \& S. L. Fales. (Eds.). Grassland: Quietness and Strength for a New American Agriculture. Madison, WI: Alliance of Crop, Soil and Environmental Science Societies.

Karsten, H. D., Patterson, P. H., Stout, R., \& Crews, G. (2010). Vitamin A, E, and Fatty Acid Composition of the Eggs of Caged Hens and Pasture Hens. Renewable Agriculture and Food Systems, 25, 45-54. http://dx.doi.org/10.1017/S1742170509990214

King, F. H. (1911). Farmers of Forty Centuries or Permanent Agriculture in China, Korea, and Japan. Emmaus, PA: Rodale Press. http://dx.doi.org/10.5962/bhl.title.20418

Kirschenmann, F. (2007). Potential for a New Generation of Biodiversity in Agroecosystems of the Future. Agronomy Journal, 99(2), 373-376. http://dx.doi.org/10.2134/agronj2006.0104

Masterjohn, C. (2007a). On the trail of the elusive X-factor. Wise Traditions, 8(1), 14-32.

Masterjohn, C. (2007b). Vitamin D toxicity redefined: vitamin K and the molecular mechanism. Med. Hypotheses, 68(5), 1026-34. http://dx.doi.org/10.1016/j.mehy.2006.09.051

Masterjohn, C. (2013). Nutritional Adjuncts to the Fat Soluble Vitamins. Retrieved from http://www.westonaprice.org/health-topics/abcs-of-nutrition/nutritional-adjuncts-to-the-fat-soluble-vitamins

Molnar, T. J., Kahn, P. C., Ford, T. M., Funk, C. J., \& Funk, C. R. (2013). Tree crops, a permanent agriculture: Concepts from the past for a sustainable future. Resources, 2, 457-488. http://dx.doi.org/10.3390/resources2040457

Northborne, W. (1940). Look to the Land. London. UK: Basis Books.

Paull, J. (2010). Permanent Agriculture: Precursor to Organic Farming. Elem. Biodyn. Tasman. Retrieved from http://orgprints.org/10237/1/10237.pdf

Paull, J. (2011). The making of an agricultural classic: Farmers of forty centuries or permanent agriculture in China, Korea and Japan, 1911-2011. Agric. Sci, 2, 175-180. http://dx.doi.org/10.4236/as.2011.23024

Price, W. A. (1950). Nutrition and Physical Degeneration (8th ed.) La Mesa, CA Price-Pottenger Nutrition Foundation.

Rheaume-Bleue, K. (2012). Vitamin K2 and the Calcium Paradox. New York: HarperCollins.

Rodale, J. I. (1948). The Organic Front. Emmaus, PA: Rodale Press.

Saucier, O. A., \& Parsons, R. L. (2014). Refusing to "Push the Cows": The Rise of Organic Dairying in the Northeast and Midwest in the 1970's-1980s. Agricultural History Society, 88, 237-261. http://dx.doi.org/10.3098/ah.2014.88.2.237

Smil, V. (2001). Enriching the Earth. Cambridge, MA: MIT Press.

Smith, J. R. (1950). Tree Crops: A Permanent Agriculture. New York, NY: Devin-Adair.

Sustainable Agriculture Research and Education Program. (2007). Managing Cover Crops Profitably (3rd ed.). College Park, MD: USDA Sustainable Agriculture Research and Education Program.

Tanner, C. B., \& Simonson, R. W. (1993). Franklin Hiram King-Pioneer Scientist. Soil Sci. Soc. Am. J., 57, 286-292. http://dx.doi.org/10.2136/sssaj1993.03615995005700010049x

The Rodale Institute. (2015). Tree as a Crop. Retrieved from http://rodaleinstitute.org/our-work/tree-as-a-crop/tree-as-a-crop-how-it-works/ 
USDA. (1930). Farmers' Bulletin No. 1628. Growing Black Locust Trees. Washington, D.C. Retrieved from http://archive.org/stream/growingblacklocu00matt/growingblacklocu00matt_djvu.txt

USDA. (2012). Pesticide Residue Testing on Organic Produce, 2010-2011 Pilot Study. Retrieved from http://www.ams.usda.gov/AMSv1.0/getfile?dDocName=STELPRDC5101234

USDA. (2015). Draft Guidance for Natural Resources and Biodiversity Conservation for Certified Organic Operations. Retrieved from http://www.ams.usda.gov/AMSv1.0/getfile?dDocName=STELPRDC5110083

Vivian, A. (1908). First Principles of Soil Fertility. New York, NY: Orange Judd Company. http://dx.doi.org/10.5962/bhl.title.40936

Wild Farm Alliance. (2008). Biodiversity Compliance Assessment in Organic Agricultural Systems: Summary of Major Noncompliance Indicators and Detailed Guidance of Positive Compliance Approaches. Retrieved from http://wildfarmalliance.org/resources/Biodiversity\%20Compliance.pdf

Youssefi, F., Brown, P. H., \& Weinbaum, S. A. (1999). Regulation of Nitrogen uptake at the whole-plant level: a study in almond trees. HortTechnology, 9, 598-600.

\section{Copyrights}

Copyright for this article is retained by the author(s), with first publication rights granted to the journal.

This is an open-access article distributed under the terms and conditions of the Creative Commons Attribution license (http://creativecommons.org/licenses/by/3.0/). 